\title{
Petrogenesis of Cretaceous kimberlites from the Paranatinga region, central Brazil
}

\author{
Greenwood, J.C. ${ }^{1}$, Gibson, S.A. ${ }^{1}$, Thompson, R.N. ${ }^{2}$, Weska, R.K. ${ }^{3}$ and Dickin, A.P. ${ }^{4}$
}

1. Department of Earth Sciences, University of Cambridge, Downing Street, Cambridge, CB2 3EQ, UK.

2. Department of Geological Sciences, University of Durham, South Road, Durham, DH1 3LE, UK.

3. Departmento de Recursos Minerais, Universidade Federal de Mato Grosso, Cuiabá, 78.100, Brazil.

4. Department of Geology, McMaster University, 1280 Main Street West, Hamilton, Ontario, L8S 4MI, Canada.

The Paranatinga kimberlite province is located in Mato Grosso, central Brazil $\left(14^{\circ} \mathrm{S}, 54^{\circ} \mathrm{W}\right)$. It was emplaced on the southern margin of the Amazonas craton, to the north of the Paraná basin and consists of approximately forty pipes, distributed over an area of $\sim 4,000 \mathrm{~km}^{2}$. New petrological and geochemical data from nine of these intrusions will be presented. The Brazilian kimberlites analysed to date are isotopically intermediate between Group I and Group II South African kimberlites, possibly reflecting discrete differences in their genesis. Further analyses are required to establish whether these intermediate isotopic compositions are a function of differing post-genesis interaction, or a fundamental feature of their source.

The Paranatinga kimberlites intrude (I) siltstones and sandstones of the Upper Proterozoic Diamantino formation; (ii) basaltic lavas, similar to those of the Triassic Tapirapuã formation and, (iii) in places, the basal conglomerates and sandstones of the Upper Cretaceous Parecis Group. However, they rarely outcrop and are generally buried by the fine-grained sands and silts of the Cambambe formation (which forms the uppermost unit of the Parecis group) and subsequent Quaternary laterite cover. This kimberlitic magmatism may be tentatively related to the basaltic magmatism of the Poxoréu Igneous Province (Gibson et al., 1995), which occurs in the Rio das Mortes rift, some $120 \mathrm{~km}$ to the south. This is one of several contemporaneous igneous provinces emplaced around the northern and eastern edges of the Paraná basin at approximately 85 Ma, which are believed to be associated with the impact of the Trindade mantle plume under this area (Gibson et al., 1995). Reconstructions of the plume track place the region around Paranatinga on the periphery of an $85 \mathrm{Ma}$, approximately 1,000 km in diameter, plume head (Gibson et al., 1997). Therefore it may be suggested that this kimberlitic magmatism was caused by the same heating event that produced the basaltic magmatism in the Rio das Mortes rift where the thinner lithosphere allowed a greater degree of partial melting to occur. This hypothesis is inconsistent with the U-Pb zircon age of 121.1 Ma obtained by Davis (1978). This age may however be anomalously old, as other zircon ages for kimberlites both to the east (Poço Verde, Minas Gerais) and west (Pimenta Bueno, Rondônia) of Paranatinga range from 80-90 Ma (Gibson et al., 1995). It has also been shown that kimberlitic zircon ages may not necessarily represent the actual eruption age of a pipe (Kinny et al., 1989).

The samples described here were selected from drillcores and drillchips from the Universidade Federal de Mato Grosso, along with rocks collected in the field. They range from crater to diatreme facies and display variable amounts of alteration. One sample contains some fresh olivine megacrysts, however the others display the effects of intense serpentinisation and carbonate replacement due to post-eruption hydrothermal activity. Despite this alteration, the original textural features of many samples have been well-preserved. Two petrographically distinct kimberlite types can be identified in this region. The northernmost samples are generally diatreme and crater facies kimberlite breccias. They contain megacrysts of variably serpentinised, rounded olivine, garnet 
(often surrounded by a reaction rim of phlogopite or green chlorite), ilmenite, phlogopite and rare zircon and diopside. These are set in a fine-grained, serpentinised matrix, with some patches of carbonate. All of the samples studied also contain a variable proportion of sub-angular crustal xenoliths; either basalts and / or siltstones derived from the Diamantino formation. The xenoliths also display evidence of severe alteration, with all the feldspar (in both the sediments and basalts) having been completely replaced. Some crater facies tuffs are also present, with rounded $2-5 \mathrm{~mm}$ lapilli, composed both of megacrysts and rounded country rock fragments in a fine-grained, serpentinised matrix containing smaller, often broken or kinked, crystals of garnet, phlogopite and ilmenite, along with abundant rounded pseudomorphs after olivine.

The southernmost sample (Batovi 6) is another diatreme facies breccia, although more massive in appearance than those previously described. It has also been subjected to intense serpentinisation, with all the olivine megacrysts and groundmass phases having been completely replaced by a mixture of serpentine and carbonates. The other megacrysts present include garnet (surrounded by reddish-brown reaction rims), ilmenite and rare phlogopite and diopside. The matrix contains abundant small perovskite grains. Xenoliths of basalt, siltstone and rare altered garnet lherzolites are also present.

The whole-rock geochemistry of the kimberlites reflects the petrographic differences described above. The major element geochemistry of all the samples has been affected both by alteration and crustal contamination. Using a contamination index $\left(\mathrm{SiO}_{2}+\mathrm{Al}_{2} \mathrm{O}_{3}+\mathrm{Na}_{2} \mathrm{O}\right) /\left(2 \mathrm{~K}_{2} \mathrm{O}+\mathrm{MgO}\right)$ values of 1.1 to 1.9 are obtained, with an average of 1.4 ; the highest values being recorded in the crater facies samples and the lowest in the more consolidated, diatreme breccia of Batovi 6. Contamination and alteration, have a much lesser effect on the relative abundances of incompatible trace elements.
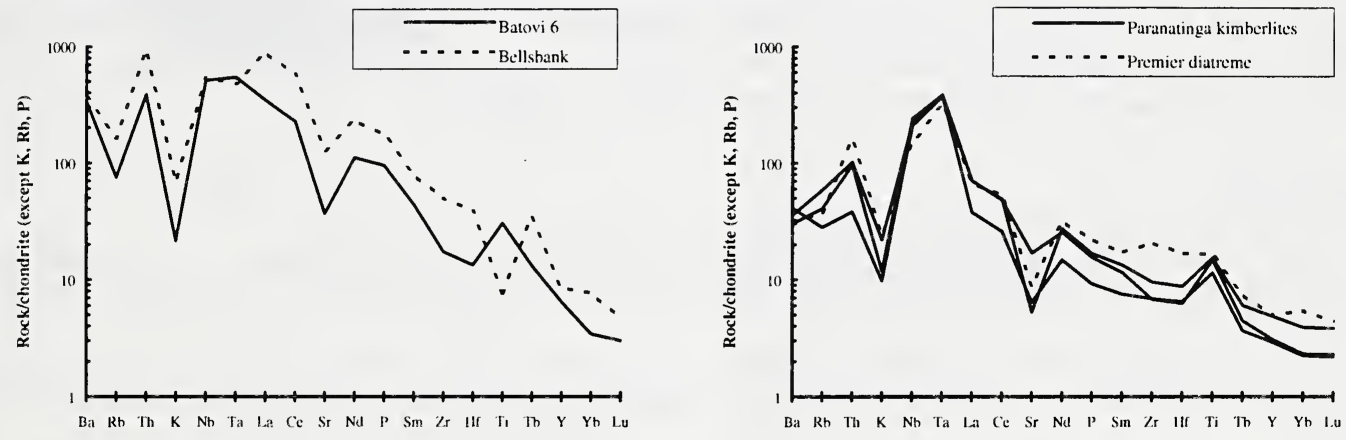

Figure 1: Normalised abundances of incompatible trace elements in: (a) the Batovi 6 kimberlite; and (b) other selected Paranatinga kimberlites. Examples of South African kimberlites are shown for comparison. Normalisation factors from Thompson et al. (1984).

The Batovi 6 kimberlite displays a normalised incompatible trace element pattern similar to that of Group I micaceous kimberlites from South Africa. Figure 1(a) shows a comparison with a sample from the Bellsbank main fissure (data from Fesq et al., 1975; Kable et al., 1975). The patterns are generally similar, with peaks in $\mathrm{Ti}$ and $\mathrm{Ta}$ in Batovi 6 being related to a greater proportion of ilmenite. Light rare earth elements (LREE) show a strong enrichment compared with the heavy rare earth elements (HREE) in this sample, with $(\mathrm{Ce} / \mathrm{Yb})_{\mathrm{N}}=65.8$. This enrichment is reflected in the presence of abundant perovskite in the groundmass, which may fractionate the LREE from the HREE, thus affecting the whole rock geochemistry. Figure 1(b) shows the different incompatible 
trace element patterns displayed by the Paranatinga kimberlites. Due to the increased amounts of crustal material assimilated by these samples and the different mineral phases present, there are considerable differences in their normalised multi-element patterns. These show similarities with other highly brecciated, crustally contaminated samples, such as the "grey" kimberlite from the Premier diatreme. The higher abundances of $\mathrm{Zr}$ and $\mathrm{Hf}$ in the Premier sample may be linked to the assimilation of zircons from the country rock. The much lower average $(\mathrm{Ce} / \mathrm{Yb})_{\mathrm{N}}$ values of 13.8 maybe due to the diluting effects of country rock addition.

The kimberlites of the Paranatinga region show significant differences, both in their petrology and geochemistry, from those of the Alto Paranaíba igneous province (e.g. Três Ranchos), although they are thought to have been formed contemporaneously, by the impact of the Trindade mantle plume under central Brazil $~ 85$ Ma (Gibson et al., 1995, 1997). The Batovi 6 kimberlite is characterised by ${ }^{87} \mathrm{Sr} /{ }^{86} \mathrm{Sr}_{85 \mathrm{Ma}}=0.70364$ and $\varepsilon \mathrm{Nd}_{85 \mathrm{Ma}}=0.94$. On a conventional $\mathrm{Sr}-\mathrm{Nd}$ isotope diagram this kimberlite falls between the field of Group 1 South African kimberlites (Smith et al., 1985) and the more isotopically enriched Três Ranchos kimberlite ${ }^{87} \mathrm{Sr} /{ }^{86} \mathrm{Sr}_{85 \mathrm{Ma}}=0.704658$ and $\varepsilon \mathrm{Nd}_{85 \mathrm{Ma}}=$ 4.22). The displacement of the Paranatinga kimberlites from the field of magmas believed to have been generated from within the Trindade mantle plume, such as the Ilha da Trindade basanites, (Halliday et al., 1992) and the Poxoréu basalts (Gibson et al., 1997), supports the concept of a contribution by lithospheric mantle-derived melts. The isotopic differences between the Brazilian kimberlites indicate varying styles of metasomatic enrichment of the sub-continental lithospheric mantle beneath the Amazonas and São Francisco cratons. The kimberlites appear to have interacted with compositionally different lithospheric melts. Their different trace element patterns, Sr- and Nd-isotopic ratios, suggest that heterogeneous lithospheric mantle metasomatism has occurred within these Brazilian cratons.

Improved understanding of the nature of the Paranatinga and Três Ranchos kimberlites should help to shed some light on the long-standing problem of the origin of alluvial diamond deposits in Brazil, and the petrogenesis of worldwide kimberlite magmas.

\section{References}

Davis, G.L., 1978, Zircons from the mantle: Carnegie Inst. Washington Yearb. 77, p. 895-897.

Fesq. H.W., Kable, E.J.D., and Gurney, J.J., 1975, Aspects of the geochemistry of kimberlites from the Premier mine, and other selected South African occurrences with particular reference to the rare earth elements: Phys. Chem. Earth., 9, p. 686-707.

Gibson. S.A., Thompson, R.N., Leonardos, O.H., Dickin, A.P., and Mitchell, J.G., 1995, The Late Cretaceous impact of the Trindade mantle plume: evidence from large-volume, mafic, potassic magmatism in SE Brazil: J. Petrology, 36, p. 189-229.

Gibson, S.A., Thompson, R.N., Weska, R.K., Dickin, A.P., and Leonardos, O.H., 1997, Late Cretaceous rift-related upwelling and melting of the Trindade starting mantle plume head beneath western Brazil: Contrib. Min. Pet., 126, p. 303-314.

Halliday, A.N., Davies, G.R., Lee, D-C., Tommasini, S., Paslick, C.R., Fitton, J.G., and James, D.E., 1992, Lead isotope evidence for young trace element enrichment in the oceanic upper mantle: Nature, 359, p. 623-627.

Kable, E.J.D., Fesq, H.W., and Gurney, J.J., 1975, The significance of the inter-element relationships of some minor and trace elements in South African kimberlites: Phys. Chem. Earth, 9, p. 709-734.

Kinny, P.D., Compston., W., Bristow, J.W., and Williams, I.S., 1989, Archaean mantle xenocrysts in a Permian kimberlite: Two generations of kimberlitic zircon in Jwaneng DK2, southern Botswana. In: Kimberlites and related rocks, Geol. Soc. Australia Spec. Pub. 14, Vol. 2, p. 833-842.

Smith, C.B., Gurney, J.J., Skinner, E.M.W., Clement, C.R., and Ebrahim, N., 1985, Geochemical character of southern African kimberlites: a new approach based on isotopic constraints: Trans. geol. Soc. S. Afr., 88, p. 267-280.

Thompson, R.N., Morrison, M.A., Hendry, G.L., and Parry, S.J., 1984, An assessment of the relative roles of crust and mantle in magma genesis: an elemental approach: Phil. Trans. R. Soc. Lond., A 310, p. 549-590. 